\title{
EFFECT OF PLANTING METHODS ON PRODUCTIVITY OF THREE RICE CULTIVARS AND IRRIGATION WATER USE EFFICIENCY IN NORTH DELTA Ibrahim, M. H. ${ }^{1}$; M. E. Meleha ${ }^{2}$; A. A. Ahmed ${ }^{1}$ and M. F. Ragab ${ }^{3}$ 1.Agron. Dept., Fac. of Agric., Kafrelsheikh Univ., Egypt. 2. Water Management Res. Inst., National Water Res. Center, Cairo, Egypt. 3. Irrigation Advisory Service (IAS) Department for Middle Delta, Egypt.
}

\begin{abstract}
Two field experiments were conducted at Water Management Research Station at El-Karada, Kafrelshiekh, Egypt, during 2009 and 2010 seasons, to study the effect of three planting patterns on productivity of three rice cultivars (Sakha101, Sakha105 and Hybrid 1) and some water relations. Rice seedling were transplanted in hills with the optimum plant population $\left(25 \mathrm{hills} / \mathrm{m}^{2}\right)$ and distributed on flat soil (Traditional method), two sides of $60 \mathrm{~cm}$ ridges and two sides of $80 \mathrm{~cm}$ beds.

The three rice cultivars exhibited significant differences in grain and straw yields in both seasons. The Hybrid 1 cultivar out-yielded the other two cultivars in the two seasons. There was no significant difference in grain and straw yields between Sakha101, Sakha105 cultivars. However, the three rice cultivars did not differ in harvest index in both seasons. Planting methods had no significant effect on grain yield, straw yield and harvest index in the two seasons.

Although, beds pattern was equivalent to traditional method in grain yield, beds pattern was lower in amount of applied irrigation water and it saved 2790 and $2501 \mathrm{~m}^{3} / \mathrm{fed}$ applied water than the traditional method in the two seasons. Water application efficiency for grain yield was increased by application of beds irrigations compared with traditional irrigation. The cultivar Sakha105 recorded the lowest amount of applied irrigation water at any planting patterns. The cultivar hybrid1 transplanted on beds recorded the highest water use efficiency in both seasons.

It can be concluded that transplanting the rice cultivar " hybrid1" on two sides of $80 \mathrm{~cm}$ beds was the recommended for optimum grain yield with less amount of applied irrigation water at Kafr El-Sheikh Governorate.
\end{abstract}

\section{INTRODUCTION}

Rice (Oryza sativa, L.) is highly water consumed, especially under the conventional irrigation method, thus saving the water is becoming a decisive factor for agricultural expansion. At the same time, a shortage of fresh water for irrigation and a necessity to search for effective on-farm water management strategies are required for increasing the water use efficiency of rice irrigation. Atta (2005) reported that using strips of furrows $(80 \mathrm{~cm})$ method as a new planting method for transplanting rice Sakha 104 cultivar saved $35.8 \%$ of applied water. Atta et al., (2006) indicated that irrigation water applied was $9028.6,10047.6$ and $15628.6 \mathrm{~m} 3 / \mathrm{ha}$ for planting on strips of furrows, 80 and $60 \mathrm{~cm}$ wide, and traditional planting, respectively. Meleha et al.(2008) revealed that means of irrigation water applied were 1480,1013 and $919 \mathrm{~mm}$ for traditional planting method, planting on bottom of furrows and beds, respectively. Maha (2009) stated that the traditional transplanting 
Ibrahim, M. H. et al.

method received the highest amount of irrigation water, with average of two seasons $(6680.50 \mathrm{~m} 3 / \mathrm{fed}$.), while the treatment planting in bottom of beds received the lowest amount of irrigation water with average of two seasons (4002.5 m3/fed.), El-Refaee et al. (2011), revealed that hybrid and cultivar (Egyptian hybrid 1 and SK2058H) achieved the highest grain yield production and the highest values of water use and utilization efficiency. Giza 171 (long duration cultivar ) achieved the highest amount of water input, the lowest values of water use, water utilization and water application efficiencies and the highest percentage of water loss. However, short duration cultivars ( Giza 177 , Giza 182 ,Sakha 102, sakha 103 and Sakha 105 ) recorded the lowest values of total water input and water loss as well as gave the highest value of water use efficiency and water application efficiency. Ahmed and Meleha (2012) stated that planting in bottom of beds led to significant increase in water use efficiency and achieved water saving of 4798 and 4788 $\mathrm{m}^{3} / \mathrm{ha}$ (2016 and $2012 \mathrm{~m}^{3} / \mathrm{fed}$.) than traditional transplanting method in the first and second seasons, respectively. The aim of this study was to investigate effect of planting methods on productivity of some rice varieties and their efficiency of using irrigation water in North Delta.

\section{MATERIALS AND METHODS}

Two field experiments were conducted at Water Management Research Station at El-Karada, Kafrelshiekh, Egypt, during 2009 and 2010 seasons, to study the effect of three planting patterns on productivity of three rice cultivars (Sakha101, Sakha105 and Hybrid 1) and some water relations in North Delta. The preceding crop was wheat in both seasons.

The physical and chemical properties of the soil were determined according to Black et al. (1965) and presented in Table 1.

The seed of three rice cultivars were used at the rate of $10 \mathrm{~kg} \mathrm{fed}^{-1}$ for the cultivar Hybrid 1 and $40 \mathrm{~kg} \mathrm{fed}^{-1}$ for the two inbred cultivars, i.e. Shakha 101 and Shakha 105 . Pre-germinated seeds were uniformly broadcast in the nursery on $7^{\text {th }}$ may in 2009 and 2010 seasons. Seedlings were carefully pulled form nursery after 28 days and transferred to the permanent field. Seedlings were handling transplanted in hills with the optimum population (25hills $\left./ \mathrm{m}^{2}\right)$ at the rate of 1-2 and 3-4 seedlings/hill for $\mathrm{cv}$. Hybrid 1 and the two inbred cultivars, respectively. The optimum hills population was distributed on three planting patterns as follows:

1. on flat soil (Traditional) at $20 \times 20 \mathrm{~cm}$ distance between hills and rows.

2. on two sides of $60 \mathrm{~cm}$ ridges at $13 \mathrm{~cm}$ distance between hills on each side.

3. on two sides of $80 \mathrm{~cm}$ beds at $10 \mathrm{~cm}$ distance between hills on each side. 
J. Soil Sci. and Agric. Eng., Mansoura Univ., Vol. 3 (8), August, 2012

Table (1):some physic-chemical characteristics of soil used for experimentation.

\begin{tabular}{|c|c|c|c|}
\hline Symbol & Unit & 2009 & 2010 \\
\hline Soil properties & & wheat & Wheat \\
\hline Coarse sand & $\%$ & 2.51 & 1.95 \\
\hline Fine sand & $\%$ & 18.08 & 17.32 \\
\hline Silt & $\%$ & 28.11 & 28.62 \\
\hline Clay & $\%$ & 51.29 & 51.1 \\
\hline Texture class & & clayey & Clayey \\
\hline $\mathrm{pH}(1: 2.5$ ext.) & & 8.3 & 8.1 \\
\hline EC (in soil paste extract) & $\mathrm{dS} \mathrm{m}^{-1}$ & 1.99 & 2.1 \\
\hline \multicolumn{4}{|l|}{ Soluble Cations: } \\
\hline $\mathrm{Ca}^{2+}$ & Meq/L & 4.8 & 5 \\
\hline $\mathrm{Mg}^{2+}$ & Meq/L & 4.5 & 4.8 \\
\hline $\mathrm{Na}^{+}$ & $\mathrm{Meq} / \mathrm{L}$ & 11.94 & 14 \\
\hline $\mathrm{K}^{+}$ & $\mathrm{Meq} / \mathrm{L}$ & 17 & 14 \\
\hline \multicolumn{4}{|l|}{ Soluble Anions: } \\
\hline $\mathrm{Co}_{3}{ }^{2-}$ & Meq/L & 0 & 0 \\
\hline $\mathrm{HCO}_{3}^{-}$ & $\mathrm{Meq} / \mathrm{L}$ & 8.5 & 8.6 \\
\hline $\mathrm{Cl}^{-}$ & Meq/L & 3.5 & 3.7 \\
\hline $\mathrm{SO}_{4}{ }^{2-}$ & Meq/L & 9.42 & 12.15 \\
\hline
\end{tabular}

The sub plot size was $37.44 \mathrm{~m}^{2}(7.2 \times 5.2 \mathrm{~m})$. Each plot included either 12 ridges or 9 beds with 5.2 length. To avoid the lateral movement of water and to achieve more water control, each block was separated by two meter-wide ditches. The other usual agricultural practices of growing rice for each cultivar were performed as the recommendation of Rice Research and Training Center (RRTC).

The grain and straw yields were recorded from an area of $12.48 \mathrm{~m}^{2}$ $(2.4 \times 5.2 \mathrm{~m})$ at the center of each sub-plot. The grains moisture content was measured and then grain yield was adjusted to $14 \%$ moisture content. Harvest index was calculated.

Amount of irrigation water applied was measured by a rectangular sharp crested weir. The discharge was calculated using the following formula

Where:

$$
Q=\mathrm{CLH}^{312} \quad \text { (Masoud ,1967) }
$$

$\mathrm{Q}=$ the discharge in cubic meters per second.

$L=$ the length of the crest in meters.

$\mathrm{H}=$ the head in meters.

$\mathrm{C}=\mathrm{An}$ Empirical coefficient that must be determined from discharge measurements.

Water productivity index (field water use efficiency) was calculated according to Michael (1978).

Data collected were statistically analyzed according to Gomez and Gomez (1984). 
Ibrahim, M. H. et al.

\section{RESULT AND DISCUSSION}

\section{A.Yields and harvest index:}

Grain and straw yields (t/ha) and harvest index of some rice cultivars as affected by planting method and their interaction during 2009 and 2010 seasons are presented in Table 2.

The three rice cultivars exhibited significant differences in grain and straw yields in both seasons. The Hybrid 1 cultivar out-yielded the other two cultivars in the two seasons. There was no significant difference in grain and straw yields between Sakha101, Sakha105 cultivars. However, the three rice cultivars did not differ in harvest index in both seasons. The varietal differences in grain and straw yields are reflected different genetic make up.

Planting methods had no significant effect on grain yield, straw yield and harvest index in the two seasons. In this connection, Atta et al. (2006) Meleha et al (2008) and Chunlin (2010) they reported that beds method recorded the highest yield and yield components compared with traditional transplanting method.

Table 2: Grain and straw yields ( $t / h a)$ and harvest index of three rice cultivars as affected by planting method and their interaction during 2009 and 2010 seasons.

\begin{tabular}{|c|c|c|c|c|c|c|}
\hline Factor & \multicolumn{2}{|c|}{ Grain Yield (t/ha) } & \multicolumn{2}{c|}{ Straw Yield (t/ha) } & \multicolumn{2}{c|}{ Harvest index (\%) } \\
\hline & $\mathbf{2 0 0 9}$ & $\mathbf{2 0 1 0}$ & $\mathbf{2 0 0 9}$ & $\mathbf{2 0 1 0}$ & $\mathbf{2 0 0 9}$ & $\mathbf{2 0 1 0}$ \\
\hline Cultivar: & & & & & & \\
\hline Hybrid 1 & $5.15 \mathrm{a}$ & $5.11 \mathrm{a}$ & $7.10 \mathrm{a}$ & $7.23 \mathrm{a}$ & 0.42 & 0.42 \\
\hline Skakha 105 & $4.31 \mathrm{~b}$ & $4.26 \mathrm{~b}$ & $6.15 \mathrm{~b}$ & $6.17 \mathrm{~b}$ & 0.41 & 0.41 \\
\hline Skakha 101 & $4.29 \mathrm{~b}$ & $4.24 \mathrm{~b}$ & $6.11 \mathrm{~b}$ & $6.06 \mathrm{c}$ & 0.41 & 0.41 \\
\hline F-test & ${ }^{\star *}$ & ${ }^{\star *}$ & ${ }^{\star *}$ & & $\mathrm{Ns}$ & $\mathrm{Ns}$ \\
\hline Planting method: & & & & & & 0.42 \\
\hline Ridges & 4.67 & 4.60 & 6.55 & 6.52 & 0.42 & 0.41 \\
\hline Traditional & 4.59 & 4.52 & 6.50 & 6.56 & 0.41 & 0.42 \\
\hline Beds & 4.50 & 4.50 & 6.30 & 6.38 & 0.41 & 0.41 \\
\hline F-test & $\mathrm{Ns}$ & $\mathrm{Ns}$ & $\mathrm{Ns}$ & $\mathrm{Ns}$ & $\mathrm{Ns}$ & $\mathrm{Ns}$ \\
\hline Interaction & $\star$ & $\mathrm{Ns}$ & $\mathrm{Ns}$ & $\mathrm{Ns}$ & $\mathrm{Ns}$ & $\mathrm{Ns}$ \\
\hline
\end{tabular}

*, ** and Ns indicate $p<0.05,<0.01$ and not significant, respectively. Means of each treatment followed by the same letter are not significantly different at $5 \%$ level, according to Duncan's multiple range tests.

\section{B. Irrigation water relations:}

B.1. Seasonal irrigation water applied:

Data in Tables 3and 4 show the total water applied as influenced by planting methods and rice cultivars. The obtained data showed that the total water applied were 1526, 1049 and $857 \mathrm{~mm}$ for cv. Sakha 101, 1521,1044 and $952 \mathrm{~mm}$ for cv. Hybrid 1 and 1451, 989 and $902 \mathrm{~mm}$ for cv. Sakha 105 in traditional transplanting, ridges and beds methods, respectively, in the first season. In the second season, the total water applied were 1536, 1058 and $865 \mathrm{~mm}$ for cv. Sakha 101, 1536, 1058 and $865 \mathrm{~mm}$ for cv. Hybrid 1 and 1464,1001 and $813 \mathrm{~mm}$ for cv. Sakha 105 in traditional) transplanting, ridges and beds methods, respectively. 
It was evident that traditional transplanting received the highest amount of irrigation water, while the bed method received the lowest amount of irrigation water during the two seasons, respectively. This difference between the two planting methods could be attributed to shortening the time of application of irrigation water where we added the water by required depth only beneath the furrows or beds, while in the traditional method the whole field is inundated with irrigation water, which most of it may be lost due to seepage and percolation. These results are in accordance with those reported by Atta (2005), Devinder et al (2005), Atta et al (2006), Meleha et al (2008) and Maha (2009).

Table (3): Irrigation water applied in $\mathrm{mm}$ as related to planting methods and rice cultivars during 2009 season.

\begin{tabular}{|l|c|c|c|c|c|c|c|c|c|}
\hline \multirow{2}{*}{ Rice cultivars } & \multicolumn{2}{|c|}{ Sakha 101( mm/fed) } & \multicolumn{2}{c|}{ Hybrid 1( mm/fed) } & \multicolumn{3}{|c|}{ Sakha 105(mm/fed) } \\
\cline { 2 - 12 } & Flat & Ridge & Bed & Flat & Ridge & Bed & Flat & Ridge & Bed \\
\hline $\begin{array}{l}\text { Preparation of the } \\
\text { nursery }\end{array}$ & 23 & 23 & 23 & 23 & 23 & 23 & 23 & 23 & 23 \\
\hline $\begin{array}{l}\text { Seedling raising } \\
\text { (25day) }\end{array}$ & 36 & 36 & 36 & 36 & 36 & 36 & 36 & 36 & 36 \\
\hline $\begin{array}{l}\text { Preparation of } \\
\text { permanent field }\end{array}$ & 225 & - & - & 225 & - & - & 225 & - & - \\
\hline Planting & - & 163 & 142 & - & 163 & 142 & - & 163 & 142 \\
\hline June & 340 & 218 & 204 & 340 & 218 & 204 & 340 & 218 & 204 \\
\hline July & 520 & 331 & 311 & 520 & 331 & 311 & 520 & 331 & 311 \\
\hline August & 307 & 218 & 186 & 307 & 218 & 186 & 307 & 218 & 186 \\
\hline September & 75 & 60 & 55 & 70 & 55 & 50 & - & - & - \\
\hline Total & 1526 & 1049 & 857 & 1521 & 1044 & 952 & 1451 & 989 & 902 \\
\hline
\end{tabular}

Table (4): Irrigation water applied in $\mathrm{mm}$ as related to planting methods and rice cultivars in 2010 season.

\begin{tabular}{|c|c|c|c|c|c|c|c|c|c|}
\hline \multirow[t]{2}{*}{ Rice cultivars } & \multicolumn{3}{|c|}{ Sakha 101( mm/fed) } & \multicolumn{3}{|c|}{ Hybrid $1(\mathrm{~mm} / \mathrm{fed})$} & \multicolumn{3}{|c|}{ Sakha $105(\mathrm{~mm} / \mathrm{fed})$} \\
\hline & Flat & Ridge & Bed & Flat & Ridge & Bed & Flat & Ridge & Bed \\
\hline $\begin{array}{l}\text { Preparation of the } \\
\text { nursery }\end{array}$ & 24 & 24 & 24 & 24 & 24 & 24 & 24 & 24 & 24 \\
\hline $\begin{array}{l}\text { Seedling raising } \\
\text { (25day) }\end{array}$ & 35 & 35 & 35 & 35 & 35 & 35 & 35 & 35 & 35 \\
\hline $\begin{array}{l}\text { Preparation of } \\
\text { permanent field }\end{array}$ & 227 & - & - & 227 & - & - & 227 & - & - \\
\hline Planting & & 165 & 145 & & 165 & 145 & & 165 & 145 \\
\hline June & 345 & 220 & 205 & 345 & 220 & 205 & 345 & 220 & 205 \\
\hline July & 525 & 335 & 215 & 525 & 335 & 215 & 525 & 335 & 215 \\
\hline August & 308 & 222 & 189 & 308 & 222 & 189 & 308 & 222 & 189 \\
\hline September & 72 & 57 & 52 & 72 & 57 & 52 & & & \\
\hline Total & 1536 & 1058 & 865 & 1536 & 1058 & 865 & 1464 & 1001 & 813 \\
\hline
\end{tabular}

\section{B.2. Water saving:}

Water saving represents the difference between the actual water applied for conventional irrigation using by farmer per feddan and quantity of water applied to each treatment. Data in Table (5) indicate that the amounts of water saving were 2007.60, 2007.60 and, $944.60 \mathrm{~m} 3 / \mathrm{fed}$. for sakha 101, hybrid 1 and sakha 105, respectively under furrow method, while it were 
$2818.20,2818.20$ and $2734.20 \mathrm{~m} 3 / \mathrm{fed}$. for the previous treatment, respectively under bed method in 2009 season. While it were 2003.40, 2003.40 and $1940.40 \mathrm{~m} 3 / \mathrm{fed}$. and $2809.8,2389.80$ and $2305.8 \mathrm{~m} 3 / \mathrm{fed}$. for the previous rice cultivars under furrow and bed methods, respectively in 2010 season as compared with traditional method. These results are in accordance with those obtained by Atta 2005, Atta et al (2006), Meleha et al (2008) and Maha (2009).

In general, it can be concluded that water is fast becoming an economically scarce resource in many areas of the world. So the use of transplanting in bottom of bed becomes very important to save water.

Table (5): Total water applied (m3/fed.) and amount of water saving $\mathrm{m} 3 /$ fed in both 2009 and 2010 seasons.

\begin{tabular}{|c|c|c|c|c|c|}
\hline \multirow[b]{2}{*}{$\begin{array}{l}\text { Planting } \\
\text { method }\end{array}$} & \multirow[b]{2}{*}{ Cultivar } & \multicolumn{2}{|c|}{2009 season } & \multicolumn{2}{|c|}{2010 season } \\
\hline & & $\begin{array}{c}\text { Total water } \\
\text { applied } \\
\text { (m³/fed.) }\end{array}$ & $\begin{array}{l}\text { Water saving } \\
\left(\mathrm{m}^{3} / \text { fed. }\right)\end{array}$ & $\begin{array}{c}\text { Total water } \\
\text { applied } \\
\text { (m³/fed.) }\end{array}$ & $\begin{array}{c}\text { Water saving, } \\
\left(\mathrm{m}^{3} / \text { fed. }\right)\end{array}$ \\
\hline \multirow[t]{4}{*}{ Flat (A1) } & Sakha 101 & 6451.2 & & 6409.2 & \\
\hline & Hybrid 1 & 6451.2 & & 6388.2 & \\
\hline & Sakha 105 & 6148.8 & & 6094.2 & \\
\hline & Average & 6350.4 & & 6297.2 & \\
\hline \multirow[t]{3}{*}{ Ridge (A2) } & Sakha 101 & 4443.6 & 2007.6 & 4405.8 & 2003.4 \\
\hline & Hybrid 1 & 4443.6 & 2007.6 & 4384.8 & 2003.4 \\
\hline & Sakha 105 & 4204.2 & 1944.6 & 4153.8 & 1940.4 \\
\hline \multirow[t]{4}{*}{ Bed (A3) } & Sakha 101 & 3633 & 2818.2 & 3599.4 & 2809.8 \\
\hline & Hybrid 1 & 3633 & 2818.2 & 3998.4 & 2389.8 \\
\hline & Sakha 105 & 3414.6 & 2734.2 & 3788.4 & 2305.89 \\
\hline & Average & 3560.2 & & 3795.4 & \\
\hline
\end{tabular}

\section{B.3. Water productivity index (field water use efficiency):}

One of the most extensively used terms to evaluate the performance of an irrigation system is "water efficiency". In general terms, water efficiency is defined as the ratio between the amount of water that is used for an intended purpose and the total amount of water input within a spatial domain of interest.

Data given in Table (6) showed that the highest value was recorded $(1.629$ and $1.535 \mathrm{~kg} / \mathrm{m} 3)$ for bed treatment followed by furrow (1.356 and $1.367 \mathrm{~kg} / \mathrm{m} 3$ ), while lowest value was obtained under traditional treatments $(0.740$ and $0.752 \mathrm{~kg} / \mathrm{m} 3)$ during the first and second seasons, respectively. Similar results were obtained by Atta (2005), Atta et al (2006), Meleha et al (2008), Maha(2009), Ahmed and Meleha(2012). 
Table (6): water production index as affected by different planting methods and rice cultivars in 2009 and2010 seasons.

\begin{tabular}{|c|c|c|c|c|c|c|c|}
\hline planting & \multirow[t]{2}{*}{ cultivar } & \multicolumn{3}{|c|}{2009 season } & \multicolumn{3}{|c|}{2010 season } \\
\hline method & & $\begin{array}{c}\text { Total water } \\
\text { applied } \\
\text { (m³/fed.) }\end{array}$ & $\begin{array}{l}\text { Grain } \\
\text { yield } \\
(\mathbf{k g} / \mathrm{fed})\end{array}$ & $\begin{array}{c}\text { water } \\
\text { efficiency }(\mathbf{k g} \\
\left.\text { grain } \backslash \mathrm{m}^{3}\right)\end{array}$ & $\begin{array}{c}\text { Total } \\
\text { water } \\
\text { applied } \\
\left(\mathrm{m}^{3} / \text { fed. }\right)\end{array}$ & $\begin{array}{l}\text { Grain } \\
\text { yield } \\
(\mathbf{k g} / \text { fed })\end{array}$ & $\begin{array}{c}\text { water } \\
\text { efficiency }(\mathrm{kg} \\
\left.\text { grain } \backslash \mathrm{m}^{3}\right)\end{array}$ \\
\hline \multirow[t]{3}{*}{ Flat (A1) } & Sakha 101 & 6451.2 & 4748 & 0.74 & 6409.2 & 4820 & 0.752 \\
\hline & Hybrid 1 & 6451.2 & 6006 & 0.931 & 6388.2 & 59287 & 0.928 \\
\hline & Sakha 105 & 6148.8 & 4028 & 0.655 & 6094.2 & 3920 & 0.643 \\
\hline \multirow{3}{*}{$\begin{array}{c}\text { Ridge } \\
\text { (A2) }\end{array}$} & Sakha 101 & 4443.6 & 47925 & 1.079 & 4405.8 & 4960 & 1.126 \\
\hline & Hybrid 1 & 4443.6 & 6025 & 1.356 & 4384.8 & 60325 & 1.376 \\
\hline & Sakha 105 & 4204.2 & 3955 & 0.941 & 4153.8 & 3948 & 0.95 \\
\hline \multirow[t]{3}{*}{ Bed (A3) } & Sakha 101 & 3633 & 49327 & 1.358 & 3599.4 & 4997 & 1.388 \\
\hline & Hybrid 1 & 3633 & 5919 & 1.629 & 3998.4 & 6139 & 1.535 \\
\hline & Sakha 105 & 3414.6 & 415125 & 1.216 & 3788.4 & 40217 & 1.062 \\
\hline
\end{tabular}

It can be concluded that transplanting the rice cultivar " hybrid1" on two sides of $80 \mathrm{~cm}$ beds was the recommended for optimum grain yield with less amount of applied irrigation water at Kafr El-Sheikh Governorate.

\section{REFERENCES}

Ahmed, A. A. and M. E. Meleha (2012). Response of rice productivity to mineral and organic fertilizers under two planting methods .

Atta, Y.I.M. (2005). Strip transplanting of rice: a new method of increasing water use efficiency under splitting of nitrogen fertilizer. Egypt. J.of Appl. Sci.; 20 (10 B): 501-511.

Atta, Y. I. M, Meleha, M. E.; Gawish, U. M. and A. T Abd El-Aal (2006).Improving Water Production in Rice Cultivation With High Potential for Water Savings. The Arab water regional conference 2006, December 9-11-2006 (NWRC) Egypt.

Black, C.; D. Evans ; L. Ensminger and F. Clark(1965). Methods of Soil Analysis (Chemical and Microbiological) properties, part(2). Amer Soc., Agronomy, Inc. Pub., Madison, Wisconsin, U.S.A.

Chunlin, H.(2010). Effects of furroe irrigation on the growth, production, and water use efficiency of direct showing rice. The scientific world .Journal, $10 ; 1438$ - 1479.(C.F Computer search).

Devinder, S.; R. K. Mahey; K. K. Vashist; and S. S. Mahal (2005) Economizing irrigation water use and enhancing water productivity in rice (oryza sativa L.) through bedlfurrow planting. Environment and Ecology, 23(3):606-610.

EL-Refaee, I. S., E. E. Gewaily, E. S. Naeem and B. A. Zayed (2011). Water balance and economic evaluation of some Egyptian rice cultivars .J .Agric .Res .Kafer El-Sheikh Univ .,37(1)2011.

Gomez, K. and A. Gomez (1984).Statistical Procedures of Agricultural Research .John wiley and Sons.Inc., New York, U.S.A. 


\section{Ibrahim, M. H. et al.}

Massoud, F. I. (1967). Water, Soil, and plant relationship. New PublicationHouse, Alexandria (in Arabic)

Maha (2009). Irrigation water management of rice crop.Ph.Thesis,Mansoura Univ,2009.

Meleha, M .E .; A. Z. El Bably ; A. A. Abd Allah and W. M. El-Khoby (2008). Producing more rice with less water by inducing planting methods in North Delta, Egypt . J. Agric. Sci. Mansoura Univ., 33(1): 805-813, 2008.

Michael, A. M. (1978). Irrigation theory and practices. Vikas publishing House putted New Delhi, Bombay.

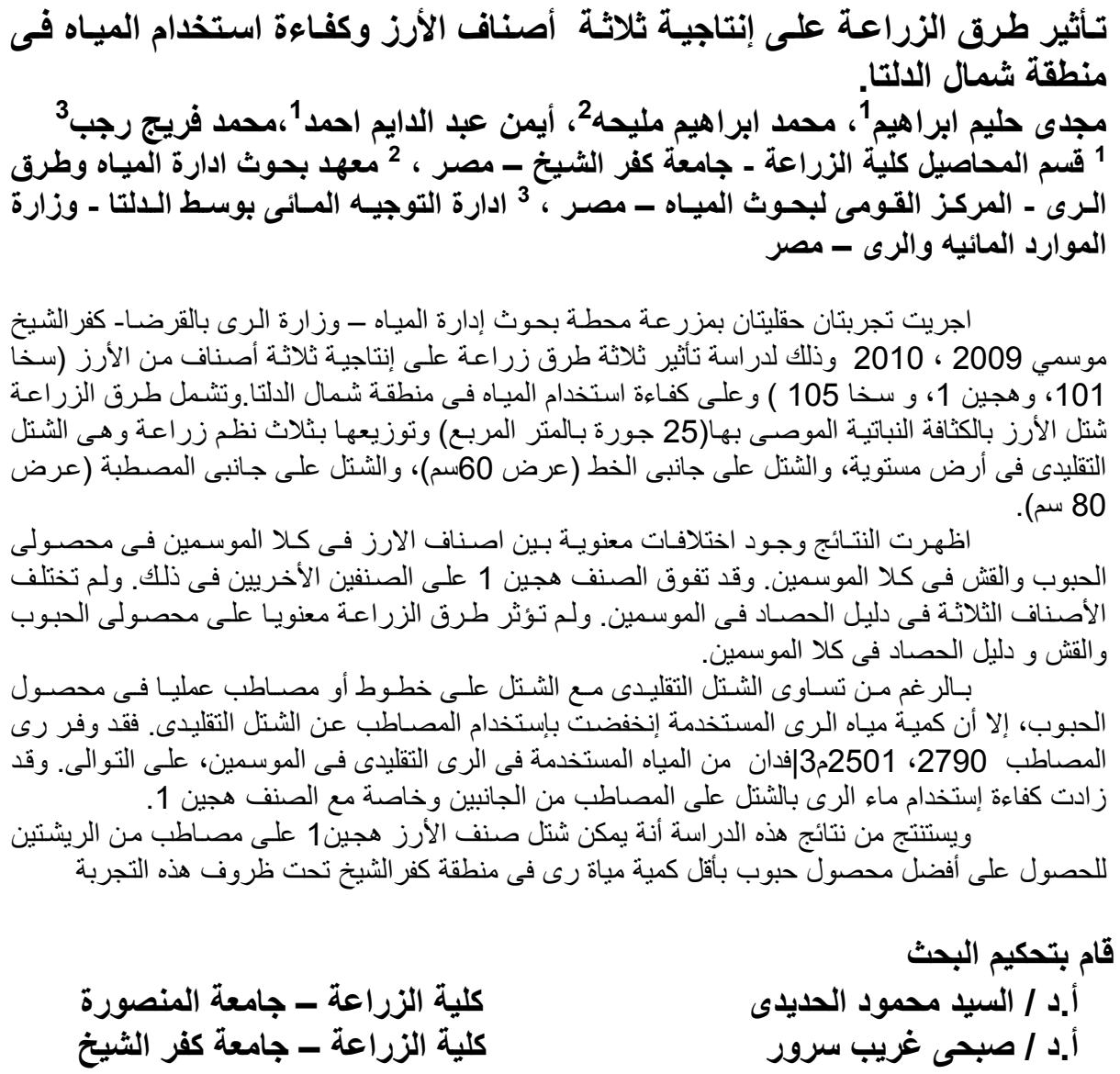


J. Soil Sci. and Agric. Eng., Mansoura Univ., Vol. 3 (8), August, 2012 